\title{
CEVAP DİLEKÇESİ VERMEYEN DAVALININ DELILL İLERİ SÜRÜP SÜREMEYECEĞİ MESELESİ
}

\author{
On Whether the Defendant, Who did not File a Reply Petition, will Put \\ Forward Evidence
}

Cenk AKÍL*

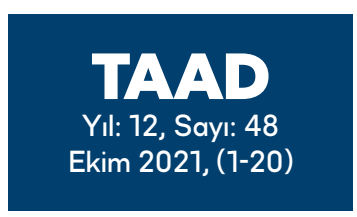

\section{Makale Bilgisi}

Geliş Tarihi : 03.01.2021

Kabul Tarihi : 11.06.2021

Makale Türü: Araştırma

\section{$\underline{\text { Article Info }}$}

Received Date: 03.01.2021

Accepted Date: 11.06.2021

Article Type : Research

\section{ÖZET}

Medeni yargıda davalı cevap dilekçesi vermek mecburiyetinde değildir. Cevap dilekçesi vermeyen davalı Hukuk Muhakemeleri Kanunu'nun 128. maddesi uyarınca davacinın iddialarını inkâr etmiş sayılmaktadır. Cevap dilekçesi vermeyen davalıya delillerini ileri sürebilmesi için mahkeme tarafından süre verilip verilemeyeceği ve böyle bir davalının ne zamana kadar delil ileri sürebileceği tartışmalıdır. 6100 sayılı Hukuk Muhakemeleri Kanunu'yla, delillerin ileri sürülmesi bakımından, 1086 sayılı mülga Hukuk Usulü Muhakemeleri Kanunu'na kıyasla daha katı bir anlayış benimsenmiştir. Bu çalışmada cevap dilekçesi vermeyen davalının delil ileri sürme hakkının kapsamı hem ilk derece yargılaması hem de kanun yolu aşaması bakımından konuya ilişkin Yargıtay kararları ve doktrinde savunulan görüşler ışığında ele alınacaktır.

Anahtar Kelimeler: Medeni usul hukuku, cevap dilekçesi, davanın inkârı, delillerin ileri sürülmesi.

\begin{abstract}
In civil court, the defendant is not obliged to file a reply petition. A defendand who does not submit a request for answers is considered to have denied all the facts asserted by the plaintiff (art. 128 the law on Civil Procedure 6100). It is debatable whether a defendant who has not filed a response petition can be given time by the court to put forward his evidence, and how long such a defendant can put forward evidence. With the law on Civil Procedure 6100 , a stricter understanding was adopted in terms of asserting evidence compared to the former law on Civil Procedure of 1086. In this study, the scope of the defendant's right to submit evidence, which does not submit a response petition, will be considered in the light of the decisions of the Supreme Court and the opinions defended in the doctrine on this issue in terms of both the first instance trial and the legal path stage.
\end{abstract}

Keywords: Law of civil procedure, pleading, denial of all facts asserted by the plaintiff, providing evidence

Bu makale Etik Kurul İznine tabi değildir.

* Prof. Dr., Beykent Üniversitesi Hukuk Fakültesi, akilcenk@hotmail.com, https://orcid.

org/0000-0003-3662-0124. 
IIIIIIIIII

\section{GİRIŞ}

Medeni yargıda (yazılı yargılama usulünde) davacının delillerini kural olarak dava ve cevaba cevap dilekçesinde davalının ise cevap ve ikinci cevap dilekçesinde ileri sürebileceği kabul edilmiştir ${ }^{1,2}$. Buna karşılık, cevap dilekçesi vermeyen $^{3}$ davalının delil ileri sürüp süremeyeceği ayrıca düzenlenmemiştir ${ }^{4}$. Bilindiği üzere, cevap dilekçesi vermeyen ${ }^{5}$ davalı HMK m. 128 uyarınca davacının iddialarını inkâr etmiş sayılmaktadır ${ }^{6}$. Gerek doktrinde gerekse yargı kararlarında cevap dilekçesi vermeyen ve bu nedenle kanunen davacının iddialarını inkâr etmiş sayılan davalının da inkâr sınırları içinde kalmak kaydıyla delil ileri sürebileceği hemen hemen ittifakla kabul edilmektedir? Bununla birlikte, cevap dilekçesi vermeyen davalının bunu yapabilmesi için mahkemenin ona süre verip veremeyeceği (veya onun bu konuda mahkemeden süre talep edip edemeyeceği) ve en son ne zamana kadar delil ileri sürebileceği

1 Davacı açısından bkz. HMK m. 119/1-f, davalı açısından bkz. HMK m. 129/1-e ve her ikisi açısından bkz. HMK m. 136.

2 Delillerin dilekçelerde ileri sürülmesi bakımından iki yöntem akla gelebilir. Bunlardan biri ileri sürülen her bir vakıanın ardından onun hangi delillerle ispat edileceğinin açıkça yazılmasıdır. İkincisi ise vakıalar ile delillerin ayrı ayrı zikredilmesinden sonra ayrı bir liste ile hangi vakıanın hangi delille ispat edileceğinin açıklanmasıdır [Özekes, Muhammet: "HMK Bakımından Dava Dilekçesinde Eksiklik Hâlinde Yapılması Gereken İşlemler", (DEÜHFD, 2014, C. 16, s. 263-300), s. 276].

3 Davalının cevap vermemesi iki sebepten kaynaklanıyor olabilir: Gerçekten de davalı bunu bilinçli olarak yapmış olabileceği gibi, cevap dilekçesinin verilmesi için tanınan süreyi de kaçırmış olabilir. Şayet davalı ikinci sebepten dolayı cevap verememişse -Kanun' daki şartlar dairesinde- eski hale getirme yoluna (HMK m. 95 vd.) başvurabilir (Pekcanıtez, Hakan: Pekcanitez Usul Medeni Usul Hukuku, 15. B., İstanbul 2017, s. 1202).

4 Umar'a göre cevap dilekçesi vermeyen davalı HMK m. 191 uyarınca karşı ispat faaliyetinde bulunabilir ve bu meyanda delil ileri sürebilir; HMK m. 129/1-e'de bahsedilen deliller bunlar olmayıp "savunmanın dayanağı olarak" ileri sürülen vakıaların ispatı amacıyla ileri sürülen delillerdir. Bkz. Umar, Bilge: Hukuk Muhakemeleri Şerhi, 2. B., Ankara 2014, s. 589.

5 Belirtmek gerekir ki, cevap dilekçesi vermeyen davalının cevap verme hakkı düşmez. O, daha sonra da cevap dilekçesi sunup inkâr dışında savunma sebepleri ileri sürebilir. Ancak bunların dikkate alınabilmesi için davacının bunlara açıkça onay vermesi gerekir (Umar, s. 411). Aynı yönde: Kuru, Baki: İstinaf Sistemine Göre Yazılmış Medeni Usul Hukuku Ders Kitab1, 3. B., Ankara 2019, s. 185.

6 "İnkâr"dan kasıt; "uyuşmazlık konusu olayların davacının ileri sürdüğ̈̈ gibi değil, başka şekilde gerçekleştiği veya doğru olmadı̆̆ ve buna bağll olarak davacinın iddiasının (talebinin) gerçek olmadiğ yahut davacının dayandiğı vakıaların kendisine bir hak tanımadiğıdır.” Bkz. Yılmaz, Ejder: Hukuk Muhakemeleri Kanunu Şerhi, C. 2, 3. B., Ankara 2017, s. 1913.

7 Bkz. Arslan, Ramazan/Yılmaz, Ejder/Taşpınar Ayvaz, Sema/Hanağası, Emel: Medeni Usul Hukuku, 6. B., Ankara 2020, s. 351. Buna karşılık, Yardımcı, süresi içinde cevap dilekçesi vermeyerek davacının iddialarını inkâr etmiş sayılan davalının sonradan hiçbir surette delil ileri süremeyeceğini belirtmiştir. Bkz. Yardımcı, Taner Emre: Hukuk Yargılamasında Somutlaştırma Yükü, İstanbul 2017, s. 140. 
tartışmalıdır. Aşağıda önce cevap dilekçesi vermeyen davalıya delillerini ileri sürebilmesi için süre verilip verilemeyeceği, daha sonra da cevap dilekçesi vermeyen davalının ne zamana kadar delillerini ileri sürebileceği meseleleri ele alınacaktır.

\section{I. İLK DERECE YARGILAMASINDA}

\section{A. CEVAP DÍLEKÇESI VERMEYEN DAVALIYA DELILIL ÍLERI SÜREBILMESI İÇIN SÜRE VERILIPP VERILEMEYECEĞİ}

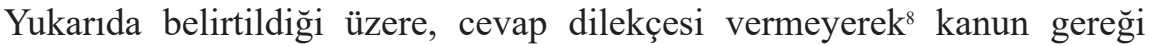
(HMK m. 128) davacının iddialarını inkâr etmiş sayılan davalının delil ileri sürme hakkı tümüyle ortadan kalmamaktadır. Bununla birlikte, kuşkusuz davalı cevap dilekçesi vermemenin bir takım olumsuz sonuçlarına katlanacaktır. $\mathrm{Bu}$ cümleden olarak davalı her şeyden önce ancak inkâr çerçevesinde ${ }^{10}$ delil ileri sürebilecektir ${ }^{11}$.

Öte yandan, cevap dilekçesi vermemiş olan davalı dava dosyasından anlaşılabilen itiraz sebeplerini' ${ }^{12}$ ve bunları ispata yarayan delilleri de ileri sürebilecektir. $\mathrm{Bu}$ noktada mahkemenin cevap dilekçesi vermeyen davalıya delillerini ileri sürebilmesi için süre verip veremeyeceği sorusunun cevaplandırılması gerekir. Konu doktrinde tartışmalıdır.

Bir görüş̧e göre, mahkeme, cevap dilekçesi vermeyen davalıya delillerini ileri sürebilmesi için süre veremez. Cevap vermeyen ve bu nedenle kanun gereği davacının iddialarını inkâr etmiş sayılan davalı ancak bu kapsamda

$8 \mathrm{Bu}$ ihtimalde davacının da ikinci cevap dilekçesi verip veremeyeceği tartışmalıdır. Egemen görüşe göre, bu durumda, davacı ikinci cevap dilekçesi veremeyecektir. Hepsi yerine bkz. Kuru, Baki: Medeni Usul Hukuku El Kitab1, C. 1, Ankara 2020, s. 504. Aksi yönde: Özkaya-Ferendeci, H. Özden: "Davalının Cevap Dilekçesi Vermemesi Halinde M. 128'in Uygulanması ve Ortaya Çıkan Sorunlara İlişkin Çözüm Arayışları”, (MÜHFHAD, 2018/1, s. 258-269), s. $258 \mathrm{vd}$.

9 Özkaya-Ferendeci, s. 260; Görgün, Şanal/Börü, Levent/Toraman, Barış/Kodakoğlu, Mehmet: Medeni Usul Hukuku, 9. B., Ankara 2020, s. 317-319. Bu noktada bilirkişi incelemesi (HMK m. 266) ve keşif (HMK m. 288) delillerini istisna tutmak gerekir. Zira anılan delillere taraflar dayanmasa da hâkim kendiliğinden başvurabilecektir. Bkz. Taşpınar Ayvaz, Sema: Hukuk Muhakemeleri Kanunu'nun (HMK) Zaman Bakımından Uygulanması, Ankara 2013, s. 386.

10 Buna karşılık, cevap dilekçesi vermeyen davalı inkârını ispat sadedinde zamanaşımı veya borcun ödendiği gibi iddialar ileri sürecek olursa bununla savunmayı genişletme yasağını ihlâl etmiş olur (Kuru, El Kitabı, s. 502; Akyol Aslan, Leyla: Medeni Usul Hukukunda Cevap Dilekçesi Verilmemesinin Sonuçları, Ankara 2019, s. 382 vd.).

11 Cevap dilekçesi vermeyen davalının da ön inceleme duruşmasına davet edilmesi gerektiği hakkında bkz. Kuru, Ders Kitabı, s. 183; Kuru, El Kitab1, s. 502; Akyol Aslan, s. 227.

12 Kuru, El Kitab1, s. 504. 
IIIIIIIIII

savunma yapabilir ve delil gösterebiliri ${ }^{13}$. Bununla birlikte, cevap dilekçesi vermemiş olan davalı ön inceleme aşamasından önce veya en geç ön inceleme aşamasında ıslah yoluyla cevap dilekçesi vermişse kendisine ıslah talebiyle birlikte mahkemeye sunduğu cevap dilekçesinde dayandığı delilleri sunabilmesi için ön inceleme aşamasında süre verilebilmelidir ${ }^{14}$.

Aksi yöndeki görüşe göre ise, HMK m. 128 ile sadece cevap dilekçesi verilmemesine davayı inkâr sonucu bağlanmakla yetinilmiş, buna karşılık, cevap dilekçesi vermeyen davalının sonradan hiçbir şekilde delil ileri sürümeyeceğine ilişkin yasaklayıcı bir düzenlemeye yer verilmemiştir. Cevap dilekçesinde salt davacının iddialarını inkârla yetinen ve bütün kanuni delilleri sadece ismen saymış olan bir davalıya HMK m. 139/1-ç uyarınca süre verilecekken hiç cevap dilekçesi vermeyerek aynı sonucu sağlayan davalıya süre verilemeyeceğini kabul etmek tutarlı olmayacaktır. Bu nedenlerle süresinde cevap dilekçesi vermeyen davalıya, karşı ispat (HMK m. 191) faaliyeti bağlamında inkâr savunmasıyla sınırlı olmak üzere ön inceleme aşamasında, talep etmesi halinde, delilerini ileri sürebilme imkânının tanınması doğru olacaktır; aksi düşüncenin kabulü HMK m. 128'de öngörülen inkâr sonucunu anlamsız kılacak, davada var olan "çelişme" ve "silahların eşitliği ilkesi”"ni zedeleyecek ve davalının ispat hakkı ihlâl edilmiş olunacaktır. Bu ise sonuçta hukuki dinlenilme (HMK m. 27) ve dolasıyla adil yargılanma hakkının (AY m. 36/1) ihlâli anlamına gelecektiris .

Uygulamada ise Yargitay'ın bazı daireleri, 22.07.2020 tarih ve 7251 sayılı Kanun'un ${ }^{16} 13$ ve 14. maddeleriyle sirasiyla HMK m. 139 ve 140 ' da yapilan değişikliklerden önce, cevap dilekçesi vermeyen davalıya delillerini ileri sürebilmesi için süre verilebileceğini ifade etmekte idi ${ }^{17}$.

13 Pekcanıtez, Pekcanıtez Usul, s. 1206; Akkaya, Tolga: Medeni Usul Hukuku Bakımından Boşanma Davaları, Ankara 2017, s. 367.

14 Pekcanitez, Pekcanitez Usul, s. 1207.

15 Arslan, Ramazan/Yılmaz, Ejder/Taşpınar Ayvaz, Sema/Hanağası, Emel: Medeni Usul Hukuku Pratik Çalışmaları, 17. B., Ankara 2019, s. 221; Akyol Aslan, s. 509-510; Aras, Aslı: “Cevap Dilekçesi Verilmemesinin Hukuki Sonuçları”, (DEÜHFD, Prof. Dr. Şeref Ertaş’a Armağan, C. 19, Özel Say1-2017, s. 1927-1952), s. 1938.

16 RG 28.07.2020, S. 31199.

17 Örnekler: “... Taraflar arasındaki davanın yapılan muhakemesi sonunda mahalli mahkemece verilen, yukarıda tarihi ve numarası gösterilen hüküm davalı tarafından temyiz edilmekle, evrak okunup gereği görüşülüp düşünüldü: Dava dilekçesi davalıya 26.11.2013 günü tebliğ edilmiş, davalı süresinde (HMK. m. 127/1) cevap vermemiş, 19.03.2014 günü verdiği dilekçe ile yetki itirazında bulunmuştur. 02.04.2014 tarihli dilekçesi ile de tanıklarını bildirmiştir. Davaya süresinde cevap vermemiş olan davalı, davacının dava dilekçesinde ileri sürdüğü vakıaların tamamını inkâr etmiş sayılır (HMK. m.128). Bu böyle olmakla birlikte süresinde davaya cevap vermemiş olan davalının dahi, kanunda belirtilen süre içinde olmak koşuluyla delil bildirme hakkı mevcuttur. Delil, çekişmeli hususların ispatı için gösterilir (HMK. m.187). Çekişmeli hususlar ise ön inceleme duruşmasında tespit 
Yargıtay Hukuk Genel Kurulu ise bu konuda dönüm noktası sayılabilecek bir kararında cevap dilekçesi vermemiş olan davalıya ayrıca süre verilemeyeceğini içtihat etmiştir. Kararda özetle şu görüşlere yer verilmiştir: “... Davalı cevap dilekçesi vermemiştir. Katıldı̆̆ ön inceleme duruşmasında, boşanmak istemediğini beyan etmiştir...uyuşmazllk; yasal süresinde davaya cevap vermeyen davalının, kötüye kullanılmadıkça davacı tarafin ileri sürdüğ̈̈ vakıaları çürütmeye yönelik delil bildirip bildiremeyeceği, cevap dilekçesiyle delil bildirmeyen davaliya ön inceleme duruşmasinda belirlenen uyuşmazlık konusunda delil bildirmesi için süre verilmesinin gerekip gerekmediği, varlacak sonuca göre somut olayda davaliya delil göstermesi için süre verilerek gösterdiği takdirde delilleri toplanarak hasıl olacak sonuca göre bir karar verilmesinin gerekip gerekmediği noktasında toplanmaktadır... Delillerin belirli bir zaman dilimi için de gösterilip sunulması yargılamayı çabuklaştıracak olmasının yanı sıra, taraflara da gösterilen delillerinden haberdar olarak zamanında bunlara karşı delil veya görüş bildirebilme imkânı tantyacak, böylece uyuşmazlıklar en kısa sürede adilane çözüme

edilir. (HMK. m. 140/1) Tarafların anlaştıkları ve ayrıştıkları hususlar tespit edilmeden delil göstermeleri beklenemez. Şu hâlde, taraflar kural olarak en geç tahkikatın başına kadar delil gösterebilir ve sunabilirler... Davalıya ön inceleme duruşmasında delil göstermesi ve delillerini sunması için bir süre verilmediğine göre davalının tahkikat duruşmasından önce 02.04.2014 günü verdiği tanık listesi süresinde kabul edilmelidir. Öyleyse davalının gösterdiği tanıkları dinlenip diğer delillerle birlikte değerlendirilerek hâsıl olacak neticesine göre karar verilmesi gerekir. Bu husus nazara alınmadan eksik inceleme ile hüküm kurulması doğru bulunmamıştır...”2. HD, 20.02.2015, 17538/2414 (https://karararama.yargitay.gov.tr/ YargitayBilgiBankasiIstemciWeb); "Davalının davaya süresinde cevap vermemiş olması, davacının dava dilekçesinde ileri sürdüğü vakıaların tamamının inkâr edildiği anlamıma gelir (HMK. m. 128). Bu böyle olmakla birlikte, süresinde davaya cevap vermeyen davalının, davacının davasının dayanağı olarak gösterdiği vakıaları çürütmeye yönelik delil gösterme hakkı vardır. Delil, uyuşmazlığın çözümünde etkili olabilecek çekişmeli hususların ispatı için gösterilir (HMK. m. 187/1). Uyuşmazlık konuları ise ön incelemede belirlenir. Ön inceleme duruşmasında uyuşmazlık konuları belirlenmeden, tarafların tanık listesi vermesi beklenemez. Kuşkusuz o aşamaya kadar göstermişler ise gösterdikleri delillerin toplanması için gerekli hazırlık işlemleri ön incelemede yapılacaktır (HMK. md.137/1). Ancak göstermemişlerse, çekişmeli konuların belirlenmesinden sonra bunların ispatı için taraflardan delil göstermeleri istenmelidir. Aksinin kabulü, bir kez davaya cevap vermemiş veya cevap süresini kaçırmış olan davalının, hukuki dinlenilme hakkını (HMK. md. 27) zedeler. Bu bakımdan, davalıya ön inceleme duruşmasında, davacının davasının dayanağı olarak gösterdiği vakıaları çürütmek için delil gösterme imkânı verilmeli, gösterdiği takdirde buna ilişkin delilleri tahkikat aşamasında usulünce toplanarak tüm deliller birlikte değerlendirilerek, tarafların kusur durumları ve boşanmanın fer' i sonuçları buna göre karara bağlanmalıdır. Bu hususlar nazara alınmadan eksik inceleme ile hüküm kurulması doğru bulunmamıştır..." 2. HD, 26.09.2013, E. 2013/8511, K. 2013/22057 (https://karararama.yargitay.gov.tr/YargitayBilgiBankasiIstemciWeb/pf/ sorgula.xhtml) 
IIIIIIIIII!

kavuşacaktır... 145. maddede belirtilen ve tarafin etki alanı dışında kalan çok özel durumlar dışında, sonradan delil sunulması halinde bu deliller dikkate alınmamalıdır... 6100 sayılı HMK'da düzenlemelere yer verilmiş olup, bu bağlamda delil gösterilmesi dilekçelerin teatisi (dava, cevap, cevaba cevap ve ikinci cevap) aşamasına hasredilmiştir...dava dilekçesinin davaliyla 31.05.2012 tarihinde usulüne uygun bir şekilde tebliğ edilmesinden sonra süresi içerisinde cevap dilekçesi verilmediğinden savunmanın dayanağ olarak süresinde ileri sürülen bir delil (HMK m. 129/1-e) bulunmadiğından yerel mahkemenin davallya delil göstermesi için süre vermesine yasal olarak imkân bulunmadı̆̆ının kabulü gerekir..." ${ }^{18}$.

Anılan içtihattan sonra Yargıtay dairelerinin de bu yönde kararlar verdiği görülmektedir. Örneğin: “... 6100 Sayılı HMK’nın sistematiği içinde; tahkikat aşamasina geçilmezden evvel tarafların uyuşmazlıkların çözümü için ileri sürdükleri delillerin daha işin başında belirlenerek tahkikatın etkin bir şekilde yapılmasının amaçlandı̆̆g anlaşılmaktadır. Yargılamanın etkin ve makul bir süre içinde bitirilmesi için delil gösterilmesi dilekçelerin teatisi (dava, cevap, cevaba cevap ve ikinci cevap) aşamasına hasredilmiştir. Buna göre, dilekçelerin teatisi aşamasında herhangi bir delil bildirmeyen davacı veya davaltya ön inceleme duruşmasında delillerini bildirmesi için yeni bir süre verilmesine imkân bulunmamaktadır. Somut olayda; dava dilekçesi 20.11.2012 tarihinde davalıya tebliğ edilmiş, davalı yasal süresi içinde davaya cevap vermediği gibi herhangi bir delil de bildirmemiştir. 28.02.2013 tarihli ön inceleme duruşmasinda mahkemece taraflara uyuşmazlıkla ilgili olarak hangi delillere başvurduklarının sorulması üzerine davalı delilerinin; "Ulukışla İcra Müdürlügünün 2011/138 Esas sayll dosyası ve tanılar" olduğunu beyan etmiş, ön inceleme duruşmasından sonra da tanıklarının isimlerini bildiren dilekçe vermiştir. Yukarda belirtilen yasal düzenlemeler dikkate alındiğında, usulüne uygun tebligata răgmen yasal süresi içinde davaya cevap vermediği gibi herhangi bir delil de bildirmeyen davalınin ön inceleme duruşmasinda delillerini bildirmesi ve ön inceleme duruşmasindan sonra da isim ve adreslerini bildirdiği tanıkların dinlenilmesi mümkün değildir..." ${ }_{19}$.

Kanımızca Yargıtay Hukuk Genel Kurulu tarafindan yukarıda özeti verilen kararda temsil edilen görüş daha isabetlidir. Zira Hukuk Muhakemeleri Kanunu delillerin ileri sürülmesi bakımından 1086 sayılı mülga Hukuk Usulü Muhakemeleri Kanunu'na göre daha katı bir anlayış benimsemiş ve bu meyanda anılan Kanun'un taraflara yeni delil ileri sürebilme imkânı tanıyan

18 YHGK, 20.04.2016, E. 2014/2-695, K. 2016/522 (KİBB).

19 YHGK, 20.04.2016, E. 2014/13-856, K. 2016/523 (https://hukuk.medeniyet.edu.tr). 
244. maddesine ${ }^{20}$ denk gelen bir düzenlemeye HMK'da yer verilmemiştir ${ }^{21}$. Böylelikle kanun koyucunun yargılamanın sürüncemede kalmasını engellemek gayesiyle hareket ettiği ve bu nedenle delillerin mümkün olduğunca yargılamanın başında ileri sürülmesini sağlamaya çalıştığı söylenebilir. Nitekim doktrinde de HMK'nın delillere ilişkin hükümleri karşısında tarafların delillerini prensip olarak dilekçelerin değişimi aşamasında ileri sürebilecekleri belirtilmiştir ${ }^{22}$. Öte yandan, Kanun'da cevap dilekçesi vermemek suretiyle davayı inkâr etmiş sayılan davalıya daha fazla imkân tanındığını gösteren bir hüküm de sevk edilmemiştir. Kanımızca HMK m. 191 hükmü de bu konuda aksi yöndeki görüş için haklı bir dayanak teşkil etmemektedir. Zira anılan hükümde sadece diğer tarafın, ispat yükünü taşıyan tarafın iddiasının doğru olmadığını ispat sadedinde delil ileri sürebileceği hükme bağlanmıştır; yoksa karşı ispat faaliyetine girişen tarafa ayrıca süre verileceğine ilişkin bir düzenlemeye yer verilmemiştir. Sonuç olarak, süresi içinde cevap dilekçesi vermeyen ve bu itibarla kanunen davacının iddialarını inkâr etmiş sayılan davalıya delillerini ileri sürebilmesi için ayrıca bir süre verilemeyecektir. $\mathrm{Bu}$ sonuç Kanun'da (m. 139/1-ç) verilmesi öngörülen iki haftalık süre bakımından da geçerlidir. Çünkü bahsi geçen hüküm sadece dava ve cevap dilekçesinde gösterilmekle birlikte sunulmayan belge türündeki delilleri kapsamaktadır ${ }^{23}$. Cevap dilekçesi vermeyen bir davalının ise sonradan anılan hükme istinaden belge sunması doğal olarak mümkün olmayacaktır.

Son olarak tahkim yargılamasındaki duruma kısaca değinmek faydalı olacaktır. Bilindiği üzere, HMK m. 430/1-b hükmü uyarınca "Davall, cevap

20 "Ikame ve beyan olunan delillerin tamemen istima ve tetkikından sonra iki yüz yirmi birinci madde hükmüne tevfikan ayrica tahkikat icrasına karar verilmiyen meselelerde iki taraftan her biri yeni delil ibraz ve ikamesini istiyebilir. Hâkim muvafik görürse bu talebi kabul eder."

21 HMK ile HUMK'un delillerin ikamesi bakımından karşılaştırılması için bkz. Özmumcu, Seda: "1086 Sayı1ı Hukuk Usulü Muhakemeleri Kanunu ile 6100 Sayılı Hukuk Muhakemeleri Kanunu'nun Delillerin İkamesi Hakkındaki Hükümlerine Mukayeseli Bir Bakış”, (KHD, Ocak-Şubat 2013, s. 42-66), s. 60 vd.; Kılınç, Ayşe: "Dilekçelerin Değişimi Aşamasında Delillerin Gösterilmesi ile Delillerin Hasredilmiş Olup Olmayacağı Meselesi”, (MİHDER, 2019/1, s. 105-136), s. $110 \mathrm{vd.}$

22 Erdönmez, Güray: "Hukuk Muhakemeleri Kanunu Bakımından Delillerin Gösterilmesi ve İbrazı”, (İBD, 2013/5, s. 15-53), s.18. Karş. Eroğlu, Orhan: Medeni Usul Hukukunda Davaya Cevap, Ankara 2018, s. 291. Esasen anılan son Yazar da bu görüşte ise de buna tanık delili bakımından istisna tanımaktadır. Buna göre, davalı cevap dilekçesini ve delil süresini kanuni süresinden sonra, ön inceleme duruşmasından önce sunmuş ve delil listesinde tanık deliline dayanmış ise davalının inkâr kapsamında bildirmiş olduğu tanıkların dinlenmesi gerekir.

23 Bu yönde: Atal1, Murat/Ermenek, İbrahim/Erdoğan, Ersin: Medenî Usûl Hukuku, 3. B., Ankara 2020, s. 394. Tarafların iddialarını salt "belgeyle" ispatlayacaklarını ileri sürmelerinin yeterli olmadığı, belgeyi somutlaştırması gerektiği hakkında bkz. Börü, Levent: Medenî Usûl Hukukunda İddia ve Somutlaştırma Yükü, Ankara 2016, s. 208. 
IIIIIIIIII!

dilekçesi vermezse; bu durum davacının iddialarının ikrarı veya davanın kabulü olarak değerlendirilmeyip yargllamaya devam edilir". Doktrinde ifade edildiği üzere esasen bu hüküm devlet mahkemesinde açılan davada davalının cevap vermemesi durumunda ortaya çıkan sonuçla aynı sonucu doğurmalı davalının, davacının iddialarını inkâr ettiği kabul edilmelidir²4. Öte yandan, HMK m. 430/1-c hükmü uyarınca taraflardan biri, geçerli bir neden göstermeksizin davaya katılmaz veya delillerini sunmaktan kaçınırsa hakem kurulu, tahkim yargılamasına devam ederek mevcut delillere göre karar verebilecektir. Şu halde her şeyden önce davalının cevap vermemesi durumunda dava sona ermeyecek hakem veya hakem kurulu yargilamaya devam edecektir. Bununla birlikte, bu ihtimalde davalının daha sonra delil ileri sürüp süremeyeceği belirlenirken devlet mahkemesi önünde icra edilen yargılamayla aynı sonuca ulaşılması zorunlu değildir. Zira HMK m. 428/3 uyarınca taraflar aksini kararlaştırmış olmadıkça, tahkim yargılaması sırasında iddia veya savunmasını değiştirebilecektir. Bununla birlikte, hâkim veya hakem kurulu, bu işlemin gecikerek yapılmış olduğu veya diğer taraf için haksız bir şekilde büyük zorluk yarattığı ve diğer durum ve koşulları dikkate alarak, böyle bir değişiklik veya genişletmeye izin vermeyebilir. İddia veya savunma tahkim sözleşmesinin kapsamı dışına çıkacak şekilde değiştirilemez ve genişletilemez. Şu halde, tahkim yargılamasında cevap vermeyerek davayı inkâr etmiş sayılan davalı inkârla sınırlı olmaksızın vakıa ve delil ileri sürebilecektir ${ }^{25}$.

\section{B. CEVAP DILLEKÇESI VERMEYEN DAVALININ NE ZAMANA KADAR DELILL ÍLERİ SÜREBILECEĞİ}

Yukarıda belirtildiği üzere, doktrinde cevap dilekçesi vermeyen davalının da delil ileri sürebileceği kabul edilmektedir. Bununla birlikte, davalının bunu ne zamana kadar yapabileceği konusunda farklı görüşler ortaya atılmıştır.

Bir görüşe göre, cevap vermeyen davalı ön inceleme ve tahkikat aşamasında inkâr çerçevesinde kalmak kaydıyla savunma yapabilecek ve bu yönde ispat faaliyetinde bulunarak delil gösterebilecektir ${ }^{26}$. Diğer bir görüş̧e göre ise her ne kadar cevap dilekçesi vermeyen davalının da delil ileri sürebilmesi mümkünse de bunu zamansal olarak herhangi bir sınırlamaya tâbi olmaksızın yapabileceği kabul edilemez; aksi takdirde davanın tarafları, yani davacı ile (cevap dilekçesi vermeyen) davalı arasında eşitsizlik yaratılmış olur. Öte yandan, cevap dilekçesi veren davalının, delillerini en geç ön inceleme duruşması için çıkarılacak davetiyenin tebliğinden itibaren iki hafta içinde (HMK m. 139/1-ç) sunabileceği, buna karşılık, cevap dilekçesi vermeyen davalının ise

24 Özbay, İbrahim/Korucu, Yavuz: Tahkim, Ankara 2016, s. 98; Akyol Aslan, s. 144.

25 Akyol Aslan, s. 145.

26 Pekcanitez, Pekcanıtez Usul, s. 1206; Tanrıver, Süha: Medeni Usul Hukuku, C. 1, 2. B., Ankara 2018, s. 675; Akkaya, s. 367. 
tahkikat sonuçlanıncaya kadar delil ileri sürebileceğinin kabul edilmesi de doğru olmayacaktır. Kaldı ki, tahkikat aşaması delilerin gösterildiği değil, değerlendirildiği bir aşamadır. Bu gerekçelerle, cevap dilekçesi vermeyen davalının delillerini en geç ön inceleme duruşması için gönderilen davetiyenin tebliğinden itibaren iki haftalık süre içinde ileri sürebileceği kabul edilmelidir ${ }^{27}$.

Yargıtay'ın bu konudaki içtihatlarının ise zamanla değiştiği gözlemlenmektedir. Nitekim Yargıtay daha önce vermiş olduğu bazı kararlarda cevap dilekçesi vermeyen davalının da sonradan delil ileri sürebileceğini kabul etmekteydi: “... Davaya süresi içinde cevap verilmemiş olması, davacının dava dilekçesinde ileri sürdü̈̆̈̈ vakıaların tamamının inkârı anlamına gelir (HMK. m. 128). Bu böyle olmakla birlikte, süresi içinde davaya cevap vermemiş olmak, davalının savunmasını ispat etme ve davacının ileri sürdüğ̈̈ vakıalart çürütmeye yönelik delil gösterme hakkını ortadan kaldırmaz. Eş söyleyişle, davaya süresinde cevap vermeyen davall, davacının kusurlarına yönelik olarak değil, kendisine kusur yüklenemeyeceğine iliş̧kin olarak delil bildirme hakkına sahiptir. Kaldı ki, delil taraflar arasındaki çekişmeli hususların ispatı için gösterileceğine göre, bu husus saptanmadan taraflardan delillerini sunmalarl da beklenemez. Davalı, süresinden sonra 29.03.2012 günü verdiği cevap dilekçesinde tanık deliline dayanıp, bunların isim ve adreslerini bildirmiş ve ayrıca hastane kayıtlarına da dayanmıştır. $O$ hâlde, davalının gösterdiği deliller toplanıp, diğer delilerle birlikte değerlendirilerek hâsıl olacak sonucuna göre karar verilmesi gerekirken, usulüne uygun olmayan şekilde tensiple süre verilmiş olduğundan bahisle davalının gösterdiği deliller toplanmadan eksik inceleme ile hüküm kurulması doğru bulunmamıştır... "28.

Yargıtay daireleri daha sonra, yukarıda (A) başlığı altında özetine yer verilen YHGK kararına paralel olarak, cevap dilekçesi vermeyen davalının sonradan delil ileri sürmesinin mümkün olmadığ 1 , bu meyanda ön inceleme aşamasında dahi kendisine süre verilemeyeceği yönünde kararlar vermeye başlamışlardır. Örneğin: “... Somut olayda, davalının süresinde cevap dilekçesi vermediği ve yargılamanın devamında hatta ön inceleme aşamasından da sonra, 11.02.2015 tarihinde verdiği dilekçe ile davanın esasına iliş̧kin savunmada bulunduğu ve tanıkları Kazım ile Cemile'nin dinlenmesini talep ettiği anlaşılmıştır. Davalının bu hareketi hem delilleri süresinde gösterme kuralı, hem de savunmanın genişletilmesi/değiștirilmesi yasağına aykırıdır. Buna göre süresi içinde cevap dilekçesi vermemiş davalı, davacının dava dilekçesinde ileri sürdüğü tüm vakıaları inkâr etmiş sayılır ve yukarıda belirtilen istisnalar dişında sonradan delil gösteremez ve savunmasinı genişletemez/değiştiremez. O hâlde Mahkemece, davacı tarafindan gösterilen

Akyol Aslan, s. 514.

28 2. HD, 13.05.2013, E. 2013/1548, K. 2013/13577 (Akyol Aslan, s. 516, dn. 579). 
IIIIIIIIII!

deliller değerlendirilmek suretiyle bir karar verilmesi gerekirken, süresinde cevap dilekçesi vermeyen ve dolaylstyla süresinde tanı deliline dayanmayan davalının tanıkları dinlenerek, bu tanık beyanları hükme esas alınarak karar verilmesi doğru olmamıştır... " ${ }^{29}$.

Biz doktrinde ileri sürülen ve yukarıda yer verdiğimiz görüşlerin hiçbirine bütünüyle katılamamaktayız. Kanaatimizce cevap dilekçesi vermeyen taraf kural olarak ancak dilekçeler teatisi bitinceye kadar delil ileri sürebilir. Bu itibarla cevap dilekçesi vermeyen davalı ne ön inceleme aşamasında ne de tahkikat aşamasında delil ileri sürebilecektir. Zira tahkikat aşamasında daha önce toplanmış bulunan deliller incelenir ve değerlendirilir; aksi hâlde, tahkikat tamamlanamaz ve yargılama uzar ${ }^{30}$. Öte yandan HMK m. 139/1-ç hükmü sadece cevap dilekçesinde belge deliline dayanan davalı bakımından bir anlam ifade edeceğinden cevap dilekçesi vermeyen bir davalı bu (ek) iki haftalık süreden de yararlanamayacaktır.

Öte yandan, bu meseleye ilişkin olarak bir sonuca ulaşırken HMK m. 189 ve HMK m. 145/1, c. 1 hükümleri de gözden rrak tutulmamalıdır ${ }^{31}$. Nitekim HMK m. 189 uyarınca taraflar ancak kanunda belirtilen süre ve usule uygun olarak ispat hakkına sahiptirler. HMK m. 145/1, c. 1 uyarınca ise taraflar kanunda belirtilen süreden sonra delil gösteremezler. Anılan bu iki hüküm bir arada değerlendirildiğinde tarafların delillerini dilekçelerin değişimi aşamasından sonra ileri sürebilmeleri için buna cevaz veren kanuni bir düzenlemeye ihtiyaç olduğu sonucuna ulaşmak mümkündür. Hâlbuki cevap dilekçesi vermeyen davalının dilekçelerin değiş̧imi aşamasından sonra delil ileri sürebileceğine ilişkin böyle bir düzenleme ise mevcut değildir. Kaldı ki, cevap dilekçesi verip davacının iddialarını inkâr etmekle yetinen bir davalı sadece dilekçelerin değişimi aşamasında delil ileri sürebilecekken cevap dilekçesi vermeyen bir davalıya bu konuda daha geniş imkân tanınması kanımızca eşitlik ilkesine (AY m. 10) aykırı olacağı gibi, bunun haklı bir gerekçesi de bulunmamaktadır.

Özetle; cevap dilekçesi vermeyen davalı prensip olarak sadece dilekçelerin değişimi için öngörülen süre zarfında delillerini ileri sürebilecektir. Bu itibarla yukarıda (A) başlığı alında özetine yer verilen Yargıtay Hukuk Genel Kurulu kararında bu meseleye ilişkin olarak dile getirilen görüş kanımızca daha isabetlidir ${ }^{32}$.

29 8. HD, 01.04.2019, E. 2018/3244, K. 2019/3480 (https://karararama.yargitay.gov.tr/ YargitayBilgiBankasi IstemciWeb/)

30 Özekes, Pekcanitez Usul, s. 1339.

31 Benzer şekilde: Tutumlu, Mehmet Akif: "Cevap Dilekçesi Vermeyen Davalının Delil Gösterme Hakk1 Düsser mi?”, (THD, C. 11, S. 120, Ağustos 2016, s. 134-138), s. 137; Tutumlu, Mehmet Akif: “ Cevap Dilekçesinde Gösterilmeyen Delile (Tanık) Tahkikat Aşamasında Dayanılabilir mi?”, (THD, C. 9, S. 95, Temmuz 2014, s. 116-118), s. 118.

32 Aynı yönde: Çiftçi, Pınar: "Boşanma Davalarında Delillerin Gösterilmesine ve İbrazına 
$\mathrm{Bu}$ başlık altındaki açıklamalara son vermeden önce şunu da belirtmek gerekir ki, doktrinde haklı olarak işaret edildiği üzere, süresi içinde cevap dilekçesi vermeyen davalının da daha sonra delil ileri sürebilme olanağ tümüyle ortadan kalmamaktadır ${ }^{33}$. Şöyle ki, her şeyden önce cevap dilekçesi vermeyen davalı da HMK m.145'in sunduğu imkânlardan yararlanabilir. Daha açık bir ifadeyle, cevap dilekçesi vermeyen davalı da yargılamayı geciktirmemek kaydiyla yahut daha önce ileri sürememekte kusurunun bulunmadığı hallerde inkâr çerçevesinde sonradan delil ileri sürebilecektir. Cevap dilekçesi vermeyen davalının delil ileri sürebilmesine olanak tanıyan ikinci düzenleme ise hâkimin davayı aydınlatma ödevine ilişkin HMK m.31 hükmüdür. Buna göre, mahkemenin, uyuşmazlığın aydınlatılmasının zorunlu kıldığı hâllerde, maddi veya hukuki açıdan belirsiz yahut çelişkili gördüğü hususlar hakkında, cevap dilekçesi vermeyen davalıya açıklama yaptırması, soru sormas1 ve ondan delil göstermesini istemesi mümkündür ${ }^{34}$. Fakat davalı bunu sadece dava dosyasından anlaşlabilen hususlar bakımından yapabilecektir. Zira hâkimin davayı aydınlatma ödevinin (HMK m. 31) sınırları bunlarla çizilmiştiri ${ }^{35}$. Son olarak, cevap dilekçesi vermeyen davalı, iddianın ve savunmanın değiştirilmesi ve genişletilmesi yasağının karşı tarafın rızasıyla veya ıslahla aşıldığ 1 durumlarda (bkz. HMK m. 141) da delil ileri sürebilecektir.

Yukarıda belirtildiği üzere, tahkim yargılamasında cevap dilekçesi vermeyen davalı prensip olarak savunmanın değiştirilmesi ve genişletilmesi yasağıyla bağlı olmaksızın yeni vakı ve bunun ispatı sadedinde yeni delil ileri sürebilecektir. Bununla birlikte, bu noktada HMK m. 428/3 hükmü dikkate alınmalıdır. Zira bahsi geçen hükme göre, taraflar aksini kararlaştırmış olmadıkça, tahkim yargılaması sırasında iddia veya savunmasını değiştirebilecektir. Bununla birlikte, hâkim veya hakem kurulu, bu işlemin gecikerek yapılmış olduğu veya diğer taraf için haksız bir şekilde büyük zorluk yarattığı ve diğer durum ve koşulları dikkate alarak, böyle bir değişiklik veya genişletmeye izin vermeyebilir.

İlişkin Güncel Yargıtay Hukuk Genel Kurulu Kararlarının -Önemli Bir İçtihat DeğişikliğininDeğerlendirilmesi”, (DEÜHFD, C. 20, S. 1, 2018, s. 15-61), s. 58.

33 Doktrinde bu imkânlara 1slah da ilave edilmektedir. Bkz. Y1lmaz, Ejder: "Hukuk Davalarında Delillerin Gösterilme Zamanı”, (Avukat Serdar Özersin'e Armağan, Ankara 2017, s. 11-25), s. 18.

34 Akyol Aslan, s. 516.

35 Bkz. Erdönmez, s. 16, dn. 6; Bolayır, Nur: Hukuk Yargılamasında Delillerin Toplanmasında Tarafların ve Hâkimin Rolü, İstanbul 2014, s. 151. Karş. Karaaslan, Varol: Medeni Usul Hukukunda Hâkimin Davayı Aydınlatma Ödevi, 2. B., Ankara 2019, s. 186 vd. 
IIIIIIIIIII

\section{KANUN YOLUNDA}

\section{A. İSTINAF AŞAMASINDA}

Hukukumuzda dar istinaf modeli benimsenmiş olduğundan ${ }^{36}$ ilk derece yargılaması sırasında dermeyan edilmeyen vakıaların ve delillerin istinaf aşamasında ileri sürülmesi prensip olarak caiz değildir ${ }^{37}$. Nitekim HMK m. 357/1 uyarınca, bölge adliye mahkemesince re'sen göz önünde tutulacaklar dışında ilk derece yargılaması aşamasında ileri sürülmeyen iddia ve savunmalar dinlenemeyeceği gibi, yeni delillere de dayanılamaz. Söz konusu ilkenin istisnası ise aynı maddenin üçüncü fikrasında düzenlenmiştir. Buna göre, "Illk derece mahkemesinde usulüne uygun olarak gösterildiği hâlde incelenmeden reddedilen veya mücbir bir sebeple gösterilmesine olanak bulunmayan deliller bölge adliye mahkemesince incelenebilir."

Bu hüküm ile tanınan delil ileri sürme hakkı şüphesiz cevap dilekçesi vermeyen davalı bakımından da geçerlidir. Zira cevap dilekçesi vermeyen davalı da tıpkı süresi içinde cevap dilekçesi veren davalı gibi delil ileri sürme hakkını haizdir. Bu nedenle, cevap dilekçesi vermeyen davalı inkâr savunması çerçevesinde ileri sürmek istediği delilleri usulüne uygun olarak göstermiş olduğu hâlde bunlar ilk derece mahkemesi tarafindan incelenmeden reddedilmiş idi ise yahut anılan deliller mücbir bir sebeple ${ }^{38}$ daha önce ileri sürülememişse davalı bunları istinaf aşamasında da ileri sürebilecektir ${ }^{39}$.

İstinaf derecesinde istinafa ilişkin özel hüküm bulunmayan hallerde ilk derece yargılamasına ilişkin hükümler uygulanacaktır ${ }^{40}$. Delillerin hangi şartlar altında gösterilebileceği HMK m. 357'de özel olarak düzenlendiğinden istinaf aşaması bakımından öncelikle bu hüküm uygulanacaktır. Bununla birlikte, davalının kusursuz olarak delil ileri süremediği hallerde HMK m. 145’ten kıyasen yararlanabileceği kanaatindeyiz.

\section{B. TEMYIZ AŞAMASINDA}

Cevap dilekçesi vermeyen davalının temyiz aşamasında delil ileri sürüp süremeyeceği sorusu cevaplandırılırken temyiz aşamasının niteliği göz önünde tutulmalıdır. Temyiz denetimi alt derece mahkemesi kararının hukuka uygun olup olmadığının belirlenmesiyle

36 Yıldırım, Kâmil: Hukuk Devletinin Gereği: İstinaf, İstanbul 2000, s. 45 vd.; Yılmaz, Ejder: İstinaf, 2. B., Ankara 2005, s. 57.

37 Meraklı Yayla, Deniz: İstinaf Yarg1laması, Ankara 2014, s. 106 vd.; Akil, Cenk: İstinaf Kavram1, Ankara 2009, s. 308 vd.; Akkaya, Tolga: Medeni Usul Hukukunda İstinaf, Ankara 2010, s. $272 \mathrm{vd}$.

$38 \mathrm{Bu}$ hüküm çerçevesinde mücbir sebebin uygulanma şartları belirlenirken HMK m. 145'ten kıyasen yararlanılabileceği kanısındayız.

39 Akyol Aslan, s. 519-520. Ayrıca bkz. Bolayır, Hâkimin Rolü, s. 284 vd.

40 HMK m. 360. 
sınırlı bir işleve sahiptir. Temyiz aşamasında tahkikat yapılmadığından ispat faaliyetine girişilip delil ikame edilemeyeceği konusunda doktrinin hemfikir olduğu söylenebilir ${ }^{41}$. Buna karşılık, Yargıtay’ın bu konudaki kararları istikrarlı değildir. Yargıtay bazı kararlarında davanın inkârına doktrine nazaran daha geniş bir anlam yüklemiş ve bilhassa borcu sona erdiren vakıaları da bu kapsamda mütalaa ederek temyiz aşamasında dahi borcu sona erdiren bir vakıayı ispatlamaya hizmet eden delillerin ileri sürülebileceği sonucuna varmıştır. Örneğin: “... Cevap dilekçesi vermemek suretiyle davayı inkâr eden davalının inkâra yönelik savunması, borcun mevcut olmadı̆̆ı ya da ödendiğine dair savunmayı da kapsayacağından, davalının borcun ne sebeple bulunmadığını açıklamak ve o yöndeki delillerini sunmak hakkının ortadan kalkmadı̆̆ ve cevap süresinden sonra hatta temyiz aşamasında dahi borcu söndüren bir belgenin varlı̆̆ı karşısında bunu ileri sürmek ve ibraz etmesinde savunmanın genişletilmesi yasağından söz edilemeyeceğinin kabulü zorunludur..." ${ }^{42}$.

Yargıtay'ın bu kararında vardığı sonuca katılmak mümkün değildir. Şöyle ki; davalı cevap dilekçesi vermemek suretiyle davacının ileri sürdüğü vakıaların hiç gerçekleşmediğini ya da gerçeğe aykırı olduğunu (doğru olmadığını) ileri sürmüş olmaktadır. Buna karşılık, başlangıçta doğmuş olan borcun sonradan ödeme ya da borcu sona erdiren başka bir nedenle sona erdiğinin ileri sürülmesi borcun hiç doğmadığını değil, aksine doğmuş olan borcun ödeme nedeniyle düşmüş olduğu anlamına gelir. Ödeme vakıası ise itiraz niteliğinde olup maddi hukuk anlamında itirazlar inkâr sayılamaz ${ }^{43}$.

Yargıtay daha yakın tarihli başka bir kararında ise doktrinde ileri sürülen görüşlere paralel olarak temyiz aşamasında delil ileri sürülemeyeceğini kabul etmiştir: “... (S) omut olay değerlendirildiğinde, temyiz dilekçesi ekinde ibraz edilen yıllık izin belgelerinin, yargllamanın devamı sırasında gerek davacı işçinin beyanlarında gerekse davalı işverenin savunmalarında yer almadı̆̆ olarak verilen süreye rağmen davalı tarafça ibraz edilmediği, kaldı ki davalı işveren tarafindan belgelerin yargılama aşamasında sunulmamasına yönelik bir mazeret de ileri sürülmediği gibi 12.11.2012 havale tarihli temyiz dilekçesine ek olarak verilen 04.12.2012 havale tarihli temyiz dilekçesinde aç1kça bahsi geçen belgelerin 'sehven' sunulmadı̆̆ının belirtildiği anlaşılmıştır... Buna göre yasal düzenlemeler ve yıllık izin belgelerinin niteliğ $i$ dikkate alındiğında, davalı işverenin, kanuni süresinde sunulmayan hakkın dŏgmadı̆̆ını gösteren yıllık izin belgelerine dayanması mümkün değildir..." 44 .

41 Bkz. Kuru, Ders Kitab1, s. 200; Umar, s. 411-412; Pekcanıtez, Pekcanitez Usul, s. 1206, dn. 10; Çiftçi, Pınar: Medeni Yargılama Hukukunda İspat Hakkı ve Sınırlamaları, Ankara 2018, s. 284 vd.; Eroğlu, s. 288; Akyol Aslan, s. 520.

42 15. HD, 20.02.2014, E. 2013/254, K. 2014/1189 (https://karararama.yargitay.gov.tr/ YargitayBilgiBankasi IstemciWeb/). Aynı yönde: YHGK, 09.02.2011, E. 2011/13-29, K. 2011/56; YHGK, 17.10.2007, E. 2007/19-752, K. 2007/728 (KİBB).

43 Umar, s. 412; Akyol Aslan, s. 523.

44 YHGK, 09.05.2018, E. 2018/22-422, K. 2018/1024 (KİBB). 
IIIIIIIIII!

Her ne kadar karara konu olan olayda ilk derece yargılaması sırasında delil ileri sürmeyen taraf cevap dilekçesi vermişse de Yargıtay'ın ulaştığı sonuç bakımından cevap dilekçesi veren davalı ile vermeyen davalı arasında fark bulunmamaktadır. Diğer bir deyişle, Yargıtay’ın ulaştığı sonuç cevap dilekçesi vermeyen davalı bakımından da aynen geçerli olacaktır. Sonuç itibarıyla, Yargıtay’ın yaptığı temyiz incelemesinde ne yeni bir vakıa ne de yeni bir delil ileri sürülebilecektir ${ }^{45}$.

\section{DİĞER BAZI HUKUKİ ÇARELER BAKIMINDAN}

\section{A. HÜKMÜN TASHIHHINDE}

Bazen mahkeme tarafindan verilen hükümde dosyaya bakıldığında kolaylıkla fark edilecek nitelikte ${ }^{46}$ yazı, hesap ve benzeri hatalar olabilir. İște böyle bir durumda mahkeme kendiliğinden veya taraflardan birinin talebi üzerine bunları düzeltebilir (HMK m. 304/1, c. 1). Bunun için taraflar bir dilekçeyle hükmü veren mahkemeye başvuracaklardır. Dilekçenin bir nüshası, cevap süresi mahkemece belirlenerek karşı tarafa tebliğ edilir. Cevap, tashih talebinde bulunan tarafa tebliğ olunur (HMK m. 306/1).

$\mathrm{Bu}$ yola davacı başvurabileceği gibi davalı da başvurabilir. Davalının daha önce cevap dilekçesi vermiş olup olmamasının bu konuda herhangi bir önemi bulunmamaktadır. Kanaatimizce hükmün tashihi amacıyla sınırlı olmak üzere taraflar delil de gösterebilmelidir.

\section{B. HÜKMÜN TAVZIHINDE}

Hükmün tavzihinden maksat hükümdeki belirsizliğin giderilmesi veya hükmün içerdiği çelişik sonuçların ortadan kaldırılmasıdır ${ }^{47}$. Taraflar hükmün icrasına kadar hükmün tavzihini talep edebileceklerdir (HMK m. 305/1). Hükmün tavzihinde de HMK m. 306 uygulanacağından yukarıda cevap dilekçesi vermemiş olan davalıya ilişkin açıklamalar burası için de geçerlidir.

\section{HÜKMÜN TAMAMLANMASINDA}

7251 say11 Kanun'un 27. maddesi ile HMK'ya eklenen 305/A maddesi hükmü uyarınca "Taraflardan her biri, nihâ̂ kararın tebliğinden itibaren bir ay içinde, yargılamada ileri sürülmesine veya kendiliğinden hükme geçirilmesi gerekli olmasına rağmen hakkında tamamen veya kısmen karar verilmeyen hususlarda, ek karar verilmesini isteyebilir."

$\mathrm{Bu}$ haktan davacı yararlanabileceği gibi (cevap dilekçesi vermiş ya da vermemiş) davalı da yararlanabilir. Kanaatimizce hükmün tamamlanması

45 Bolayır, Hâkimin Rolü, s. 265; Akyol Aslan, s. 523.

46 Boran Güneysu, Nilüfer: Medenî Usûl Hukukunda Karar, Ankara 2014, s. 279.

47 Arslan/Yılmaz/Taşpınar Ayvaz/Hanağası, s. 721; Boran Güneysu, s. 264. 
yoluna mahkemenin kendiliğinden hükme geçirmesi gereken hususlar hakkında başvurulmuşsa cevap dilekçesi vermiş ya da vermemiş davalı bu konuya ilişkin olarak delil ileri sürebilmelidir.

\section{YARGILAMANIN YENILENMESINDE}

Yargılamanın yenilenmesi davası kapsamında yapılan yarg1lama iadesi istenen yargılamanın devamı niteliğindedir ${ }^{48}$. Bu nedenle taraflar iddianın ve savunmanın değiştirilmesi ve genişletilmesi yasağıyla burada da bağlıdır. Bununla birlikte, (davalının yargilama sırasında elinde olmayan bir sebeple elde edemediği bir belgeyi kararın verilmesinden sonra ele geçirmesinde olduğu gibi) yargılamanın yenilenmesine yol açan sebepler dikkate alınarak davalının yeni bir delil göstermesi mümkün olabilir ${ }^{49}$. Bu hakkın kullanımı açısından cevap dilekçesi veren ve vermeyen davalı bakımından ayırım yapılması düşünülemez. Zira bu ihtimalde cevap dilekçesi vermiş olan davalı da yargılama sırasında elde edemediği bu belgeyi doğal olarak ileri sürümeyecekti.

\section{SONUÇ}

$\mathrm{Bu}$ çalışma kapsamında ulaştığımız sonuçlar şu şekilde sıralanabilir:

Mahkeme, cevap dilekçesi vermeyen davalıya talebi üzerine ya da re'sen delil ileri sürebilmesi için süre veremez.

Cevap dilekçesi vermeyen davalının HMK m. 139/1-ç hükmü uyarınca verilen iki haftalık süreden yararlanması mümkün değildir. Zira anılan düzenleme sadece dilekçe vererek belge deliline dayanan taraflar bakımından bir anlam ifade etmektedir.

Cevap dilekçesi vermeyen davalının HMK m. 145 ve HMK m. 31'deki şartlar dairesinde delil ileri sürmesi mümkün olabilir.

Cevap dilekçesi vermeyen davalı savunmanın değiştirilmesinin caiz olduğu hâllerde (HMK m. 141) delil de ileri sürebilecektir.

Tahkimde; cevap vermeyen davalı da -tahkim sözleşmesinin kapsamını aşmamak kaydıyla- prensip olarak daha sonra delil ileri sürebilecektir.

Kanun yolu aşamalarından ilki olan istinafta cevap dilekçesi vermeyen davalı prensip olarak yeni delil ileri süremeyecektir. Bununla birlikte, Kanun'da (HMK m. 357/3) öngörülen hâllerde cevap dilekçesi vermeyen davalı da -tıpk1 cevap dilekçesi veren davalı gibi- (inkâr çerçevesinde) delil ileri sürebilecektir.

48 Arslan, Ramazan: Medeni Usul Hukukunda Yargılamanın Yenilenmesi, Ankara 1977, s. 164.

49 Karş. Arslan, s. 164; Naml1, Mert: Türk ve Fransız Medenî Usûl Hukukunda Yargılamanın Yenilenmesi, İstanbul 2014, s. 464. 
IIIIIIIIII!

Temyiz aşamasında yeni bir vakıa ve delil ileri sürülemeyeceğinden cevap dilekçesi vermeyen davalı borcu sona erdiren (söndüren) bir vakıanın ispatı amaciyla dahi olsa yeni bir delil dermeyan edemeyecektir.

Yargılamanın yenilenmesinde bilhassa ileri sürülen yargılamanın yenilenmesi sebebine ilişkin olarak cevap vermeyen davalı da delil ileri sürebilecektir.

\section{KISALTMALAR CETVELI}

B.

bkz. : Bakınız

C. $\quad$ : Cilt

c. : cümle

DEÜHFD : Dokuz Eylül Üniversitesi Hukuk Fakültesi Dergisi

dn. $\quad$ : dipnot

GÜHFD : Galatasaray Üniversitesi Hukuk Fakültesi Dergisi

HD : Hukuk Dairesi

HMK : 6100 sayılı Hukuk Muhakemeleri Kanunu

HUMK : 1086 sayılı mülga Hukuk Usulü Muhakemeleri Kanunu

İBD : İstanbul Barosu Dergisi

karş. $\quad$ : karşılaştırınız

KİBB : : Kazancı İçtihat Bilgi Bankası

KHD : Kazanc1 Hukuk Dergisi

m. $\quad$ : madde

MİHDER : Medeni Usul ve İcra İflâs Hukuku Dergisi

MÜHFHAD : Marmara Üniversitesi Hukuk Fakültesi Hukuk Araştırmaları Dergisi

s. $\quad$ : sayfa

THD : Terazi Hukuk Dergisi

vd. $\quad$ : ve devami

YHGK : Yargitay Hukuk Genel Kurulu

ZÜHFD : Z Zirve Üniversitesi Hukuk Fakültesi Dergisi 


\section{KAYNAKÇA}

Akyol Aslan, Leyla: Medeni Usul Hukukunda Cevap Dilekçesi Verilmemesinin Sonuçları, Ankara 2019.

Akkaya, Tolga: medeni Usul Hukuku Bakımından Boşanma Davaları, Ankara 2017.

Aras, Asl1: "Cevap Dilekçesi Verilmemesinin Hukuki Sonuçları”, (DEÜHFD, Prof. Dr. Şeref Ertaş’a Armağan, C. 19, Özel Say1-2017, s. 1927-1952).

Arslan, Ramazan: Medeni Usul Hukukunda Yargilamanın Yenilenmesi, Ankara 1977.

Arslan, Ramazan/Yılmaz, Ejder/Taşpınar Ayvaz, Sema/Hanağası, Emel: Medeni Usul Hukuku, 6. B., Ankara 2020.

Arslan, Ramazan/Yılmaz, Ejder/Taşpınar Ayvaz, Sema/Hanağası, Emel: Medeni Usul Hukuku Pratik Çalışmaları, 17. B., Ankara 2019.

Aşık, İbrahim: Güncel Yargıtay Kararları Işı̆̆ında Dava ve Cevap Dilekçesinin Unsurlar1", (ZÜHFD, 2014, s. 145-175).

Atal1, Murat/Ermenek, İbrahim/Erdoğan, Ersin: Medenî Usûl Hukuku, 3. B., Ankara 2020.

Bolayır, Nur: "Bir Hukuk Genel Kurulu Kararı Işı̆ğında Temyiz İncelemesi Sırasında Yeni Delil Gösterilip Gösterilemeyeceği Sorunu”, (GÜHFD, 2012/2, s. 131-151), s. $141 \mathrm{vd}$.

Bolayır, Nur: Hukuk Yargılamasında Delillerin Toplanmasında Tarafların ve Hâkimin Rolü, İstanbul 2014, (Bolayır, Hâkimin Rolü).

Boran Güneysu, Nilüfer: Medenî Usûl Hukukunda Karar, Ankara 2014.

Börü, Levent: Medenî Usûl Hukukunda İddia ve Somutlaştırma Yükü, Ankara 2016.

Budak, Ali Cem/Karaaslan, Varol: Medeni Usul Hukuku, 4. B., Ankara 2020.

Çiftçi, Pınar: Medeni Yargılama Hukukunda İspat Hakkı ve Sınırlamaları, Ankara 2018.

Çiftçi, Pınar: Boşanma Davalarında Delillerin Gösterilmesine ve İbrazına İlişkin Güncel Yargıtay Hukuk Genel Kurulu Kararlarının -Önemli Bir İçtihat Değişikliğinin- Değerlendirilmesi”, (DEÜHFD, C. 20, S. 1, 2018, s. 15-61).

Erdönmez, Güray: "Hukuk Muhakemeleri Kanunu Bakımından Delillerin Gösterilmesi ve İbrazı", (IBBD, 2013/5, s. 15-53).

Görgün, Şanal/Börü, Levent/Toraman, Barış/Kodakoğlu, Mehmet: Medeni Usul Hukuku, 9. B., Ankara 2020. 
IIIIIIIIII!

Karaaslan, Varol: Medeni Usul Hukukunda Hâkimin Davayı Aydınlatma Ödevi, 2.B., Ankara 2019.

Kılınç, Ayşe: "Dilekçelerin Değişimi Aşamasında Delillerin Gösterilmesi ile Delillerin Hasredilmiş Olup Olmayacağ 1 Meselesi”, (MİHDER, 2019/1, s. 105-136).

Kuru, Baki: İstinaf Sistemine Göre Yazılmış Medeni Usul Hukuku Ders Kitabı, 3. B., Ankara 2019, (Kuru, Ders Kitab1).

Kuru, Baki: Medeni Usul Hukuku El Kitab1, C. 1, Ankara 2020, (Kuru, El Kitab1).

Namll, Mert: Türk ve Fransız Medenî Usûl Hukukunda Yargılamanın Yenilenmesi, İstanbul 2014.

Özbay, İbrahim/Korucu, Yavuz: Hukuk Muhakemeleri Kanunu Çerçevesinde Tahkim, Ankara 2016.

Özekes, Muhammet: "HMK Bakımından Dava Dilekçesinde Eksiklik Halinde Yapılması Gereken İşlemler”, (DEÜHFD, 2014, C. 16, s. 263-300).

Özekes, Muhammet: Pekcanıtez Usul Medeni Usul Hukuku, C. II, 15. B., İstanbul 2017.

Özkaya-Ferendeci, H. Özden: "Davalının Cevap Dilekçesi Vermemesi Halinde M. 128'in Uygulanması ve Ortaya Çıkan Sorunlara İlişkin Çözüm Arayışları”, (MÜHFHAD, 2018/1, s. 258-269).

Özmumcu, Seda: "1086 Sayılı Hukuk Usulü Muhakemeleri Kanunu ile 6100 Sayılı Hukuk Muhakemeleri Kanunu'nun Delillerin İkamesi Hakkındaki Hükümlerine Mukayeseli Bir Bakış", (KHD, Ocak-Şubat 2013, s. 42-66).

Pekcanitez, Hakan: Pekcanitez Usul Medeni Usul Hukuku, C. II, 15. B., İstanbul 2017.

Postacıoğlu, İlhan/Altay, Sümer: Medeni Usul Hukuku Dersleri, 7. B., İstanbul 2015.

Tanrıver, Süha: Medeni Usul Hukuku, C. 1, 2. B., Ankara 2018.

Taşpınar Ayvaz, Sema: Hukuk Muhakemeleri Kanunu'nun Zaman Bakımından Uygulanmas1, Ankara 2013.

Tutumlu, Mehmet Akif: "Cevap Dilekçesi Vermeyen Davalının Delil Gösterme Hakkı Düşer mi?”, (THD, C. 11, S. 120, Ağustos 2016, s. 134-138).

Tutumlu, Mehmet Akif: “ Cevap Dilekçesinde Gösterilmeyen Delile (Tanık) Tahkikat Aşamasında Dayanılabilir mi?”, (THD, C. 9, S. 95, Temmuz 2014, s. 116-118). 

Prof. Dr. Cenk AKİL

Umar, Bilge: Hukuk Muhakemeleri Şerhi, 2. B., Ankara 2014.

Yardımcı, Taner Emre: Hukuk Yargılamasında Somutlaştırma Yükü, İstanbul 2017.

Yıldırım, Kâmil: Hukuk Devletinin Gereği: İstinaf, İstanbul 2000.

Y1lmaz, Ejder: İstinaf, 2. B., Ankara 2005.

Yılmaz, Ejder: Hukuk Muhakemeleri Şerhi, C. 2, 3. B., Ankara 2017.

Yılmaz, Ejder: "Hukuk Davalarında Delillerin Gösterilme Zamanı", (Avukat Serdar Özersin'e Armağan, Ankara 2017, s. 11-25). 
20 咅 